\title{
Site U1310
}

\author{
Expedition 304/305 Scientists ${ }^{2}$
}

\section{Chapter contents}

Principal results ..............

Operations summary. ...........

Figure................... 4

Table ....................

${ }^{1}$ Expedition 304/305 Scientists, 2006. Site U1310. In Blackman, D.K., Ildefonse, B., John, B.E., Ohara, Y., Miller, D.J., MacLeod, C.J., and the Expedition 304/305 Scientists. Proc. IODP, 304/305: College Station TX (Integrated Ocean Drilling Program Management International, Inc.). doi:10.2204/ iodp.proc.304305.104.2006

${ }^{2}$ Expedition 304/305 Scientists' addresses.

\section{Principal results}

Site U1310 is located $\sim 10 \mathrm{~km}$ west of the center of the rift valley. Towed ocean-bottom instrument and DSL120 side-scan sonar data and bathymetry indicate that the site is on a small faultbound horst, $\sim 600 \mathrm{~m}$ east of the break in slope inferred to mark the termination of the detachment fault exposed on the central dome. The site coincides with the eastern end of Alvin dive 3643, cruise AT3-60, in an area with numerous small northeast-striking scarps (both southeast and northwest facing) (see Fig. F36 in the "Expedition 304/305 summary" chapter). Based on nearby Alvin observations and sampling, these scarps expose pillow basalts.

A push test at the end of the camera survey indicated there was as much as $6 \mathrm{~m}$ of unlithified microfossil ooze in Hole U1310A $\left(30^{\circ} 11.49^{\prime} \mathrm{N}, 42^{\circ} 03.93^{\prime} \mathrm{W} ; 2582.8 \mathrm{mbsl}\right)$. No coring was attempted at this site, but $\sim 1 \mathrm{~kg}$ of broken basaltic material was recovered from the hammer drill casing when it returned to the rig floor. The dominant rock type is sparsely plagioclase-phyric finegrained pillow basalt. A single $\sim 10 \mathrm{~cm}$ pillow fragment has a palagonitized glass rim grading through a spherulitic zone to a microcrystalline interior. The remaining material ranges in size from $\sim 5 \mathrm{~cm}$ to dust. It includes palagonitized glass fragments, some of which are encrusted by calcareous sediment and/or ironmanganese oxides, angular and drill-rounded fine-grained basalt fragments, minor calcareous sediment, and iron manganese oxides. The finer material includes separate fragments and coatings of ferrous and siliceous welding slag derived from assembly and disassembly of the bottom-hole assembly (BHA).

The first core recovered from Hole U1310B $\left(30^{\circ} 11.48^{\prime} \mathrm{N}\right.$, $42^{\circ} 03.92^{\prime} \mathrm{W} ; 2582.7 \mathrm{mbsl}$ ) contained $1.3 \mathrm{~m}$ of fist-sized and smaller pieces of basalt from the $13.5 \mathrm{~m}$ interval below a $5 \mathrm{~m}$ thick sediment cover. Although we cored as deep as $23 \mathrm{~m}$, the second core barrel was still in the lower BHA when it severed, so no rock was recovered from below 18.5 mbsf. Most of the basalt fragments recovered from Core 304-U1310B-1R are broken; alteration along these fracture surfaces is minimal and the interior is $<1 \%$ altered, suggesting the fragments are derived from in situ pillows. The piece interiors are also almost unaltered. Vesicles compose $3 \%-5 \%$ of the pieces analyzed. Vesicles close to fracture surfaces are internally discolored brown but not filled; spherulitic zones appear light brown in places, and within these zones, plagioclase 
appears white rather than transparent. Some fragments have a glassy rim 1-3 $\mathrm{mm}$ thick with relatively fresh glass. Thin zones of palagonite are mostly confined to the outer pillow surface. Glass samples were taken for onshore analysis (see 304GLASS.XLS in "Supplementary material").

In thin section, the pillow interiors appear fresh, with 5\%-10\% seriate plagioclase needles and radiating clusters in a glassy groundmass characterized by branching, feathery quench textures. Sparse anhedral olivine and prismatic plagioclase microphenocrysts are no more than $0.5 \mathrm{~mm}$ in size, with rare grains up to several millimeters in long dimension. Crystal clots composed of subophitic intergrowths of plagioclase and olivine are relatively common. Major and trace element geochemistry suggests that the basalt is a primitive tholeiite in composition. The basalt has $49.35 \mathrm{wt} \% \mathrm{SiO}_{2}, 10.23 \mathrm{wt} \% \mathrm{MgO}, 9.66 \mathrm{wt} \%$ $\mathrm{Fe}_{2} \mathrm{O}_{3}, 15.21 \mathrm{wt} \% \mathrm{Al}_{2} \mathrm{O}_{3}, 11.94 \mathrm{wt} \% \mathrm{CaO}, 2.02 \mathrm{wt} \%$ $\mathrm{Na}_{2} \mathrm{O}, 0.05 \mathrm{wt} \% \mathrm{~K}_{2} \mathrm{O}$, and $0.95 \mathrm{wt} \% \mathrm{TiO}_{2}$. Site $\mathrm{U} 1310$ basalt has 7.8 ppm Ba, 72 ppm Sr, 23.9 ppm Y, 48.2 ppm Zr, 234 ppm V, and 34.3 ppm Sc. Sample 304U1310B-1R-1, 16-18 cm, is characterized by high $\mathrm{Mg}$ and low trace element contents, consistent with the observation of olivine microphenocrysts noted in thin section.

\section{Operations summary}

\section{Hole U1310A}

After successfully installing the hard rock reentry system (HRRS) and deepening Hole U1309D to 131 mbsf, we made the $3 \mathrm{nmi}$ transit to Site U1310 using the vessel's dynamic positioning system. We elected to transit with the pipe down to allow us to map the seafloor with the subsea camera and to test the sediment thickness at our chosen drilling location without jeopardizing the hammer system. The camera survey revealed $\sim 2000 \mathrm{~m}^{2}$ of smooth, featureless sediment sloping down gently to the west, with rare, meter-sized outcrops of breadcrust-textured rock (Fig. F1). The location of this site is at the coordinates of the final position of a submersible Alvin dive (dive 3643, cruise AT3-60) that recovered pillow basalt fragments and documented 1-2 m high scarps of pillow basalt.

After a pipe trip, the HRRS was assembled with a prototype nonagon pilot and ring bit assembly and tested at the rig floor prior to deployment. Seafloor depth was estimated by drill pipe measurement as 2595 meters below rig floor (2584 meters below sea level). The HRRS (with 20 m of casing) started penetration at $0000 \mathrm{~h}$ on 12 December 2004, and hammer drilling continued for the next $6.75 \mathrm{~h}$. Penetra- tion during this deployment attempt was negligible, so we recovered the HRRS and determined that the pilot bit had pushed through the ring bit and jammed. After this incident, the nonagon bit system was removed and replaced with a wing-style reamer bit and casing shoe on the same casing string. In this configuration, there is no direct connection between the bit and the end of the casing.

Because we made effectively no penetration on our first attempt, we deployed this new assembly at the same location and began the second HRRS installation attempt for Hole U1310A at $2310 \mathrm{~h}$ on 12 December. Hammer drilling continued for the next $6 \mathrm{~h}$ until we were unable to maintain rotation of the drill string. We pulled the HRRS out of the hole and moved $10 \mathrm{~m}$ north of the original penetration location. After $5 \mathrm{~h}$ and $<6 \mathrm{~m}$ of penetration, we seemed to be making no progress, so the HRRS was again brought to the surface. The bit was missing gauge buttons from the outside of the wings but was otherwise undamaged. Hoping to install even a short stub of casing, we cut the casing in half, changed to another wing-style reaming bit, and removed the casing shoe.

With the subsea camera deployed, we were able to make a reentry into the shallow hole we had left during our third HRRS installation attempt and were able to advance the bit to $12 \mathrm{mbsf}$ before penetration essentially ceased. Satisfied we had sufficient casing in the hole to continue with the HRRS installation, we attempted to release the casing and retract the bit through the pipe. Release proved to be impossible, and after several hours of struggle, we were eventually able to extract the entire HRRS from the seafloor. Once the system was retrieved, we could see the casing running tool had released but the reaming arms on the bit had not retracted and the bit and hammer were firmly wedged in the bottom of the casing string, preventing release of the casing. In addition, one of the reamer arms was missing and several pieces of rock were lodged in the bit and held in the casing. These rock fragments (along with a few others recovered from earlier HRRS installation attempts at this site) were curated as Core 304-U1310A-1M (Table T1), and HRRS installation attempts ended at 1045 h on 15 December.

\section{Hole U1310B}

Following the unsuccessful attempts at initiating a borehole with the hammer system, we decided to attempt to core using the rotary core barrel (RCB) system. Because it was possible that the missing parts of the hammer bit were in Hole U1310A, we did not have the option of attempting a bare rock reentry into this hole. We offset the vessel $10 \mathrm{~m}$ east 
and initiated RCB coring in Hole U1310B at $2250 \mathrm{~h}$ on 15 December. The first coring interval was 18.5 $\mathrm{m}$ (owing to the spacing geometry of our BHA) and required $30 \mathrm{~h}$ to complete. Coring through this interval was characterized by constant high torque, and many intervals had to be drilled and then redrilled as rock fell into the hole. Weight on bit was maintained between 4000 and $6000 \mathrm{lb}$. After retrieving the first core barrel, there was at least $3 \mathrm{~m}$ of fill in the hole, which took $7 \mathrm{~h}$ to clear. The second core was taken from a $4.5 \mathrm{~m}$ interval and was completed at $1800 \mathrm{~h}$ on 17 December (after $11 \mathrm{~h}$ of rotation). A wireline run failed to recover the core barrel and damaged the core line at the sinker bars. A second wireline run was also unsuccessful, and we surmised that the lower part of the drill string had been severed. Once the pipe had been recovered, we confirmed that the bit and the lower part of the BHA were missing and presumed lost in Hole U1310B. Operations at Site U1310 were concluded at $0525 \mathrm{~h}$ on 18 December.

Publication: 3 June 2006

MS 304305-104 
Figure F1. Map of Site U1310 operations area developed from subsea camera survey observations. The survey began at $0550 \mathrm{~h}$ on 11 December, following the expanding box illustrated by the straight lines (the actual path of the camera is not plotted, but tracking the camera via sonar indicated the camera followed the ship's path). HRRS attempts are shown as Hole U1310A.

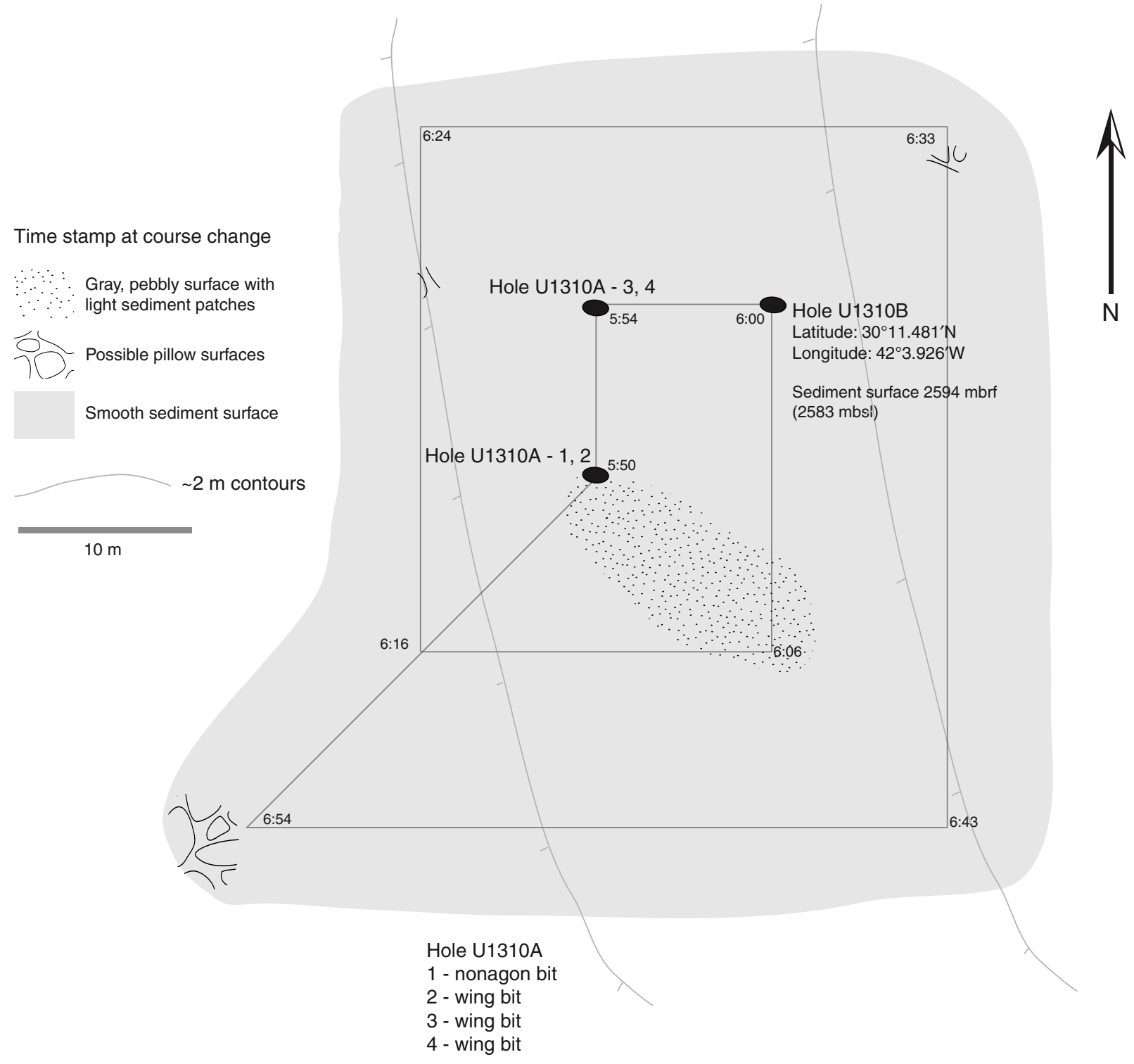


Table T1. Coring summary table, Site U1310.

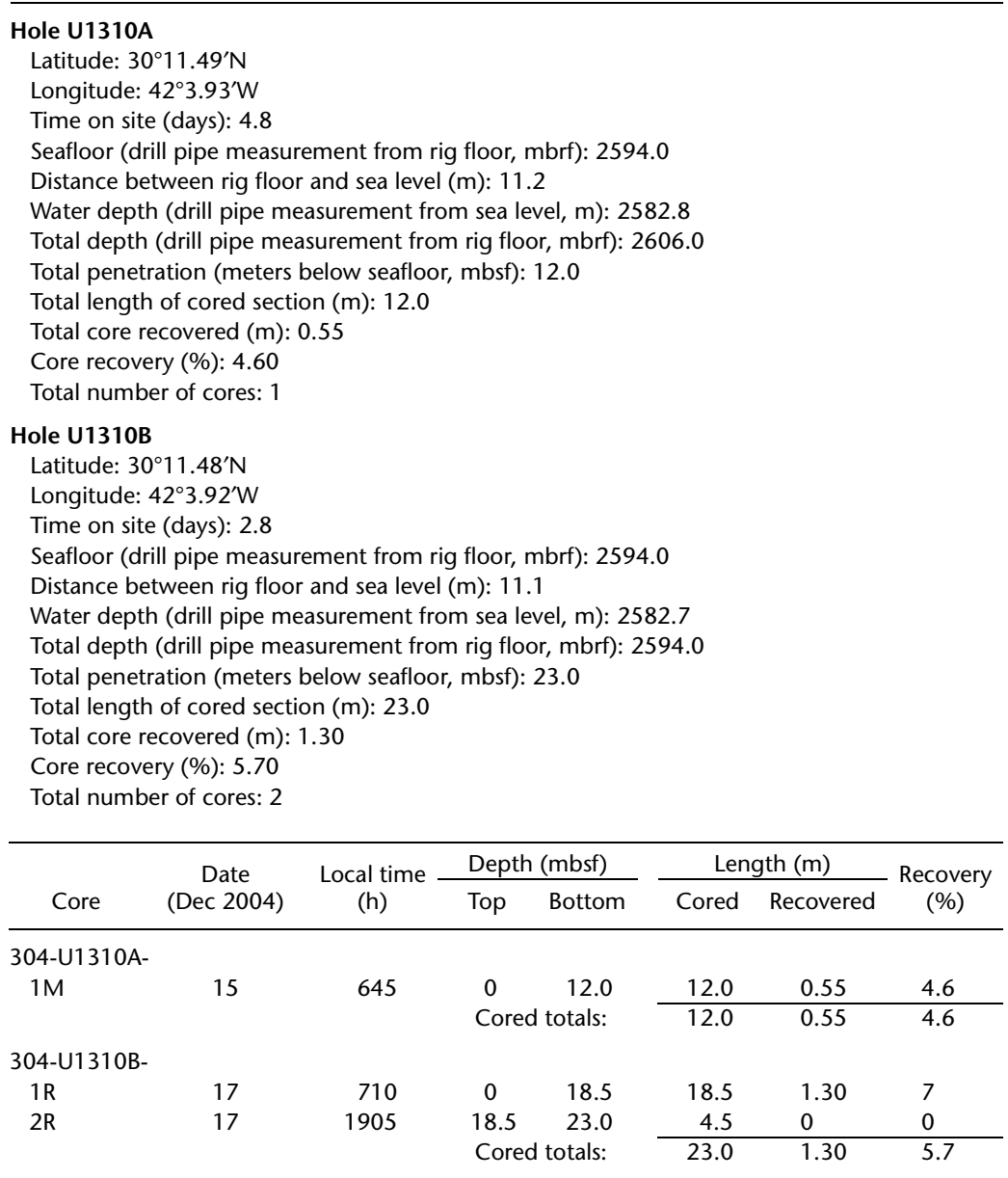

